\title{
Brittleness and Packing Density Effects on Blast-hole Cuttings Yield of Selected Rocks
}

\author{
B. Adebayo \\ Department of Mining Engineering \\ Federal University of Technology, Akure, FUTA \\ Akure, Nigeria \\ baayoakinola@googlemail.com
}

\begin{abstract}
This paper evaluates brittleness and packing density to analysis their effects on blast-hole cutting yield for three selected rocks in Nigeria. Brittleness test (S20) was carried out in accordance with Norwegian Soil and Rock Engineering and the Brittleness Index (BI) for the selected rocks were estimated. The packing density determined from the photomicrograph of the rock samples. The grain size of 45 blast-holes drill cuttings collected from three selected while drilling of these rocks were determined using standard method of America Society for Testing and Materials (ASTM) D 2487. The brittleness values are $50 \%, 44 \%$ and $42 \%$ for micro granite, porphyritic granite and medium biotite granite respectively. The result of BI varied from $10.32-11.59$ and they are rated as moderately brittle rocks. The values of packing density varied from $92.20-94.55 \%, 91.00$ $92.96 \%$ and $92.92-94.96 \%$ for all the rocks. The maximum weights of blast-hole particle size retained at $75 \mu \mathrm{m}$ are $106.00 \mathrm{~g}$, $103.28 \mathrm{~g}$ and $99.76 \mathrm{~g}$ for medium biotite granite, micro granite and porhyritic granite respectively. Packing density values have correlation to some extent with (S20) values hence, this influence the yield of blast-hole cuttings as drilling progresses. The minimum weight of blast-hole cuttings particle size retained at $150 \mu \mathrm{m}$ agrees with brittleness index classification for micro granite.
\end{abstract}

Keywords-blast-hole; cuttings; yield; brittle; index; density

\section{INTRODUCTION}

Generally a natural rock mass is non-homogenous and full of unfavorable geological structures such as joints and cracks [1]. Chaput [2]; Nicodeme [3] and Richard [4] were of the view that if depth of cut is shallow, ductile mode will dominate and the cutting will behave like grinding. The possibility is very high that when the depth of cut is deep, brittle failure may dominate since rocks generally are brittle. Pozin et al. [5] identified that rock brittleness is employed in two different ways: measure of energy consumption in the process of rock cutting/ drilling or as a physical measure of rock strength. However, Cigla et al. [6] regarded brittleness as rock property when mechanical forces an excavator are in operation. Altindag [7] and Copur, et al. [8] found that increase in the rock brittleness is accompanied by a higher specific energy of cutting which is an indication of low cutting efficiency. Goktan and Yilmaz [9] concluded that an increase in rock brittleness is accompanied by an increase in the cutting efficiency this contrary to the conclusions reached previously others. These researchers described Brittleness Index (BI) as (brittleness ratio, the brittleness coefficient or the ductility number). In addition, it is the ratio of uniaxial compressive strength to tensile strength. Hucka, and Das, [10] stated that with higher brittleness the following occurred: cracks formation as indentation, elongation values are low, fracture failure, fines formation, coupled with higher ratio of compressive strength to tensile strength. This is commonly used parameters to quantify the brittleness of rocks.

Blast-hole cuttings are generated at the bit-rock contact interface and these cuttings are progressively generated as the makes contact with new rock surface. Opafunso and Adebayo [11] described blast-hole cuttings are debris, chippings or caving flushed by compressed air rock is attacked mechanically. Adequate flushing of the blast-hole cuttings while drilling will ensure that as the bit advanced into the rock a new surface is contacted by the bit for fresh debris to be produced. Gokhale [12] was of the view that if the percentage of the annular space is less than $17 \%$ then for every $1 \%$ reduction in this percentage the bailing velocity must be increased by $2 \%$ and this may reduced the rate at which the cuttings are flushed out of the blast-hole. The other factors that may affect size distribution yield of the blast-hole cuttings are packing of the individual grains that make up the rock, type bit (sharpened, dull and worn buttons). Erosy and Waller [13] explained that textural characteristics refer to the geometrical features of rock particles and identified that matrix (packing density) is one of the textural properties of rock. They concluded that textural characteristics will go a long way to determine the mechanical behavior of rocks. Adebayo and Akande [14] correlated selected textural properties (quartz proportion, silica content, average grain size, porosity and packing density) with penetration and found that these have strong relation with penetration rate. Rock is one of the material where brittle failure dominates [15].

More importantly, it appears that the relation between rock brittleness and particle size distribution of blast-hole cuttings has not been fully established. Relatively, little published materials are available on the relation among rock brittleness, packing density and particle size distribution, hence, all these will be the focus of this paper. 


\section{EXPERIMENTAL METHODS}

\section{A. Determination of Brittleness value $\left(S_{20}\right)$}

The brittleness test is basically an aggregate impact test and this was conducted in accordance with the Norwegian soil and Rock Engineering Association (Borg, 1988). In addition $\mathrm{S}_{20}$ is defined as the percentage of material that passes the $11.2 \mathrm{~mm}$ sieve after 20 drops of $14 \mathrm{~kg}$ weight.

\section{B. Determination of Brittleness Index}

The brittle index was determined as the ratio of uniaxial compressive strength to tensile the expressed in (1).

$$
\mathrm{BI}=\frac{\mathrm{UCS}}{\mathrm{T}_{\mathrm{s}}}
$$

where BI is the brittleness index, UCS is the uniaxial compressive strength and TS is the tensile strength.

TABLE I. ROCK BRITTLENESS CLASSIFICATION (AFTER AFTES, 2003)

\begin{tabular}{|c|c|c|}
\hline Class & Brittleness Index (BI) & Description \\
\hline 1 & $>25$ & Very Brittle \\
\hline 2 & $15<\mathrm{BI}<25$ & Brittle \\
\hline 3 & $10<\mathrm{BI}<15$ & Moderately Brittle \\
\hline 4 & $\mathrm{BI}<10$ & Low Brittle \\
\hline
\end{tabular}

\section{Determiantion of Packing Density}

The packing densities for the samples were determined using (2) proposed by Kahn, (1956).

$$
\mathrm{PD}=\sum \frac{\text { Length of grains along traverse }}{\text { Length of traverse }}
$$

where, PD is the packing density (\%)

\section{RESULTS AND DISCUSSION}

Table II presents brittleness values $\left(S_{20}\right)$ for the three selected rocks. The brittleness values are $50 \%, 44 \%$ and $42 \%$ for micro granite, porphyritic granite and medium biotite granite respectively. These values are evaluated as the percentage of a pre-sieved fraction that passes through the finer sieve after 20 impacts. This revealed that more than $50 \%$ of the particle sizes pass through the finest sieve size and could be considered as the most easily broken rock to smaller fragment among the three selected rocks. Mediun biotite-granite is the least brittle while micro granite is the most brittle as presented in Table II.

Table III presents rock properties and brittleness index for the three selected rocks. The uniaxial compressive strength, tensile strength and Brittleness Index (BI) varied for 90.30 120.86 MPa, 8.25 - 10.43 MPa and 10.32 - 11.59 respectively for the selected rocks. Also, the brittleness index of micro granite is the highest make it to be the most brittle this agrees with (S20) brittleness value. In addition, this is not the case for porphyritic granite and medium boitite granite where BI rate medium biotite granite to be more brittle than porphyritic granite. The reason may that the grain size ranges that make up the rocks are marginal as well as the bonds holding the grains together as shown by the tensile strength values for the rocks in Table III and all the rocks are moderately brittle.

Table IV presents packing densities for the selected rocks. The values of packing density varied from $92.20-94.55 \%$, $91.00-92.96 \%$ and $92.92-94.96 \%$ for Micro granite, Porphyritic granite and Medium biotite granite respectively. Medium biotite granite has the most closely packed grains.

TABLE II. BRITTLENESS VALUE (S20) OF THE SELECTED ROCKS

\begin{tabular}{|c|c|}
\hline Rock name & Brittleness Value $\mathbf{( S}_{\mathbf{2 0}} \mathbf{)} \mathbf{( \% )}$ \\
\hline Micro granite & 50.0 \\
\hline Porphyritic granite & 44.0 \\
\hline Medium biotite-granite & 42.0 \\
\hline
\end{tabular}

TABLE III. ROCK PROPERTIES AND BRITTLENESS INDEX FOR THE SELECTED ROCKS

\begin{tabular}{|c|c|c|c|c|}
\hline Rock name & $\begin{array}{c}\text { UCS } \\
\text { (MPa) }\end{array}$ & $\begin{array}{c}\text { Tensile } \\
\text { Strength T } \\
\text { (MPa) }\end{array}$ & BI & Descript. \\
\hline Micro granite & 120.86 & 10.43 & 11.59 & $\begin{array}{c}\text { Moderately } \\
\text { brittle }\end{array}$ \\
\hline Porphy. Granite & 96.42 & 9.34 & 10.32 & $\begin{array}{c}\text { Moderately } \\
\text { brittle }\end{array}$ \\
\hline $\begin{array}{c}\text { Medium biotite- } \\
\text { granite }\end{array}$ & 90.30 & 8.25 & 10.95 & $\begin{array}{c}\text { Moderately } \\
\text { brittle }\end{array}$ \\
\hline
\end{tabular}

TABLE IV. PACKING DENSITIES FOR THE SELECTED ROCKS

\begin{tabular}{|c|c|c|c|c|c|}
\hline Rock type & $\begin{array}{c}\text { PD } \\
\mathbf{( \% )}\end{array}$ & $\begin{array}{c}\text { PD } \\
\mathbf{( \% )}\end{array}$ & $\begin{array}{c}\text { PD } \\
\mathbf{( \% )}\end{array}$ & $\begin{array}{c}\text { PD } \\
\mathbf{( \% )}\end{array}$ & $\begin{array}{r}\text { PD } \\
\mathbf{( \% )}\end{array}$ \\
& $\mathbf{1}$ & $\mathbf{2}$ & $\mathbf{3}$ & $\mathbf{4}$ & $\mathbf{5}$ \\
\hline Micro granite & 92.98 & 93.77 & 93.00 & 94.55 & 92.20 \\
\hline Porphyritic granite & 91.93 & 91.02 & 92.96 & 92.40 & 91.00 \\
\hline Medium biotite granite & 92.92 & 93.45 & 93.62 & 94.96 & 93.70 \\
\hline
\end{tabular}

Tables V - VII present descriptive statistics for packing density, weight of blast-hole cuttings retained at $75 \mu \mathrm{m}$ and weight of blast-hole cuttings retained at $150 \mu \mathrm{m}$ respectively. The maximum packing density values are $94.96 \%, 94.55 \%$ and $92.96 \%$ for medium biotite granite, micro granite and porphyritic granite respectively and this has correlation with $\left(\mathrm{S}_{20}\right)$ value but true to some extent for brittleness index. The maximum weights of blast-hole particle size retained at $75 \mu \mathrm{m}$ are $106.00 \mathrm{~g}, 103.28 \mathrm{~g}$ and $99.76 \mathrm{~g}$ for medium biotite granite, micro granite and porhyritic granite respectively. This revealed that the packing density has slight effect on the mechanical fragmentation of the rock. The minimum weights of blast-hole particle size retained at $150 \mu \mathrm{m}$ are $36 \mathrm{~g}, 27.68 \mathrm{~g}$ and $26.88 \mathrm{~g}$ for micro granite, medium biotite granite and porhyritic granite respectively and agrees with brittleness index classification that micro granite has most brittle response to larger fragments blast-hole cutting. The standard deviation and coefficient of variation were calculated as well summarized in Tables V-VII. The coefficient of variation describes the variability of the results. This is defined as the ratio between standard deviation of a group of test values and the population in percentage. The coefficient of variation for packing density between micro granite and porphyritic granite are a bit close, therefore their 
strength properties may be closely related. Porphyritic granite and Medium biotite granite have closer values of coefficient of variation for weight of particle size retained on $75 \mu \mathrm{m}$ sieve size. This may be the reason behind the interchange of brittleness classification with $(\mathrm{BI})$ and $\left(\mathrm{S}_{20}\right)$. The coefficient of variation for weight of blast-hole cuttings retained on $150 \mu \mathrm{m}$ varied from $9.2 \%$ for micro granite to $23.79 \%$ for porphyritic granite.

TABLE V. STATISTICS FOR PACKING DENSITY OF THE SELECTED ROCKS

\begin{tabular}{|c|c|c|c|c|c|c|c|}
\hline Rock name & N & Rang & Min & Max & Mean & Std. D & CoV \\
\hline M. granite & 5 & 2.35 & 92.20 & 94.55 & 93.30 & 0.89 & 0.95 \\
\hline P. granite & 5 & 1.96 & 91.0 & 92.96 & 91.86 & 0.86 & 0.94 \\
\hline M.B granite & 5 & 2.04 & 92.9 & 94.96 & 93.73 & 0.75 & 0.80 \\
\hline
\end{tabular}

TABLE VI. STATISTICS FOR WEIGHT BLAST-HOLES PARTICLE SIZE RETAINED AT $75 \mu \mathrm{M}$ FOR SELECTED ROCKS

\begin{tabular}{|c|c|c|c|c|c|c|c|}
\hline Rock name & N & Rang & Min & Max & Mean & Std. D & CoV \\
\hline M. granite & 15 & 40.60 & 62.68 & 103.28 & 91.56 & 14.2 & 15.56 \\
\hline P. granite & 15 & 43.16 & 56.60 & 99.76 & 83.07 & 14.8 & 17.83 \\
\hline M.B granite & 15 & 42.40 & 63.60 & 106.00 & 89.06 & 15.5 & 17.39 \\
\hline
\end{tabular}

TABLE VII. STATISTICS FOR WEIGHT BLAST-HOLES PARTICLE SIZE RETAINED AT $150 \mu$ M FOR SELECTED ROCKS

\begin{tabular}{|c|c|l|c|c|c|c|c|}
\hline Rock name & N & Rang & Min & Max & Mean & Std. D & CoV \\
\hline M. granite & 15 & 12.9 & 36.00 & 48.96 & 45.3 & 4.2 & 9.27 \\
\hline P. granite & 15 & 33.1 & 26.88 & 60.00 & 49.4 & 11.8 & 23.79 \\
\hline M.B. granite & 15 & 32.4 & 27.68 & 60.16 & 50.1 & 11.5 & 22.92 \\
\hline
\end{tabular}

Figures 1, 2 and 3 present weight retained against mean sieve size of blast-hole cuttings for micro granite, porphyritic granite and medium biotite granite respectively while drilling through fifteen blast-holes. The weight of the blast-hole cuttings retained on $850 \mu \mathrm{m}$ decreases while the retained on 75 $\mu \mathrm{m}$ increases as the drilling operation progresses from blasthole 1 to blast-hole 15 . This trend was observed in all the selected rocks and may also be a measure of the brittleness of the rock since smaller particle sizes are generated as drilling progresses.

\section{CONCLUSION}

In order to able to gain a better understanding of the mechanical fragmentation processes and select rock drill bit for a particular rock type, there is the need to analyze rock properties. However, there are different methods for evaluating brittleness and two of the methods were adopted for this work. Brittleness and packing density were related to degree of blasthole cutting yield. The following were found:

The brittleness index of micro granite is the highest which makes it to be the most brittle this agrees with $\left(\mathrm{S}_{20}\right)$ brittleness value. All the selected rocks belong to moderately brittle class this in line with AFTES (2003) rating. The maximum weights of blast-hole particle size retained at $75 \mu \mathrm{m}$ are $106.00 \mathrm{~g}$, $103.28 \mathrm{~g}$ and $99.76 \mathrm{~g}$ for medium biotite granite, micro granite and porhyritic granite respectively. This revealed that the packing density has a slight effect on the mechanical fragmentation of rocks. The minimum weights of blast-hole particle size retained at $150 \mu \mathrm{m}$ varied from $36 \mathrm{~g}$ for micro granite to $26.88 \mathrm{~g}$ for porhyritic granite and this agrees with brittleness index classification that micro granite has most brittle response to larger fragments of blast-hole cuttings. Porphyritic granite and Medium biotite granite have closer values of coefficient of variation for weight of particle size retained on $75 \mu \mathrm{m}$ sieve size. This may be the reason behind the interchange of brittleness classification with (BI) and (S20).The coefficient of variation for packing density between micro granite and porphyritic granite are a bit close, therefore their strength properties may be closely related.

\section{ACKNOWLEDGMENT}

The author would like to acknowledge the administration and technical personnel of Piccolo, and AGI, Quarries, Nigeria for providing enabling environment for acquisition of data for this research work.

\section{REFERENCES}

[1] R. E. Goodmman, Methods of Geological Engineering in Discontinuous rock, Wiley, New York, 1976

[2] E. J. Chaput, Observation and analysis of hard rocks cutting failure mechanisms using PDC cutter, Ph.D. Thesis, Imperial College, London, 1991

[3] P. Nicodeme, Transition between ductile and brittle mode in rock cutting, Rapport de stage d' Option Scientifique, Ecole Polytechnique, 1997

[4] T. Richard, Determination f rock strength from cutting test, MS Thesis, University of Minnesota, 1999

[5] E. Z. Pozin, V. Z. Melamed, S. M. Azovtseva, "Towards a method of quantitative assessment of the cuttability of coals”, Soviet Min. Sci., vol. 15, 1979, pp. 573-581, 1979

[6] M. Cigla, S. Yagiz, L. Ozdemir, “Application of tunnel boring machines in underground mine development”, 17th International Mining Congress and Exhibition of Turkey, Ankara, Turkey, 2001, pp. 155-164, 2001

[7] R Altindag, "Correlation of specific energy with rock brittleness concepts on rock cutting”, The Journal of the South African Institute of Mining and Metallurgy, Vol. 103, No. 3, pp. 163-171, 2003

[8] H. Copur, N. Bilgin, H. Tuncdemir, C. Balci, "A set of indices based on indentation tests for assessment of rock cutting performance and rock properties", The Journal of the South African Institute of Mining and Metallurgy, Vol. 103, No. 9, pp. 589-600, 2003

[9] R. M. Goktan, N. G. Yilmaz, "A new methodology for the analysis of the relationship between rock brittleness index and drag pick cutting efficiency", The Journal of The South African Institute of Mining and Metallurgy, Vol. 105, pp. 727 - 734, 2005

[10] V. Hucka, B. Das, "Brittleness determination of rocks by different methods”, Int. J. Rock Mech. Min. Sci. and Geomech. Abstr., Vol. 11, pp. 389-392, 1974

[11] Z. O. Opafunso, B. Adebayo, "Blast-hole cuttings: an indicator of drill bit wear in quarries”, European Journal of Scientific Research, Vol. 20, No. 4, pp. 721-736, 2008

[12] B.V. Gokhale, "Flushing of Blast-hole”, http://rockproducts.com, pp 1-4, 2004

[13] A. Erosy, M. D. Waller, "Textural characteristics of rocks", in: Engineering Geology, Elsevier, Netherlands, pp. 123136, 1995

[14] B. Adebayo, J. M. Akande, "Textural Properties of Rock for Penetration Rate Prediction”, Daffodil International University Journal of Science and Technology, Vol. 6, No. 1, pp 1-8, 2011

[15] G. E. Andreev, Brittle failure of rock materials. Balkema/Rotterdam, 1995 
[16] A. Borg, Hard Rock Tunnelling Boring in Norway, in: Norwegian Tunnelling Today, Norwegian Soil and Roc Engineering Association, Publication No. 5, Tapir Publisher, Trondheim, pp. 109 - 112, 1988

[17] AFTES, Guidelines for characterization of rock masses useful for the design and the construction of underground structures, Tunnels et ouvrages Souterrains, no. 177, Mail / Juin, 2003, p. 49, 2003
[18] J. S. Kahn, "The analysis and distribution of the properties of packing density and size sediments”, Journal of Geology, Vol. 64, pp 385-395, 1956

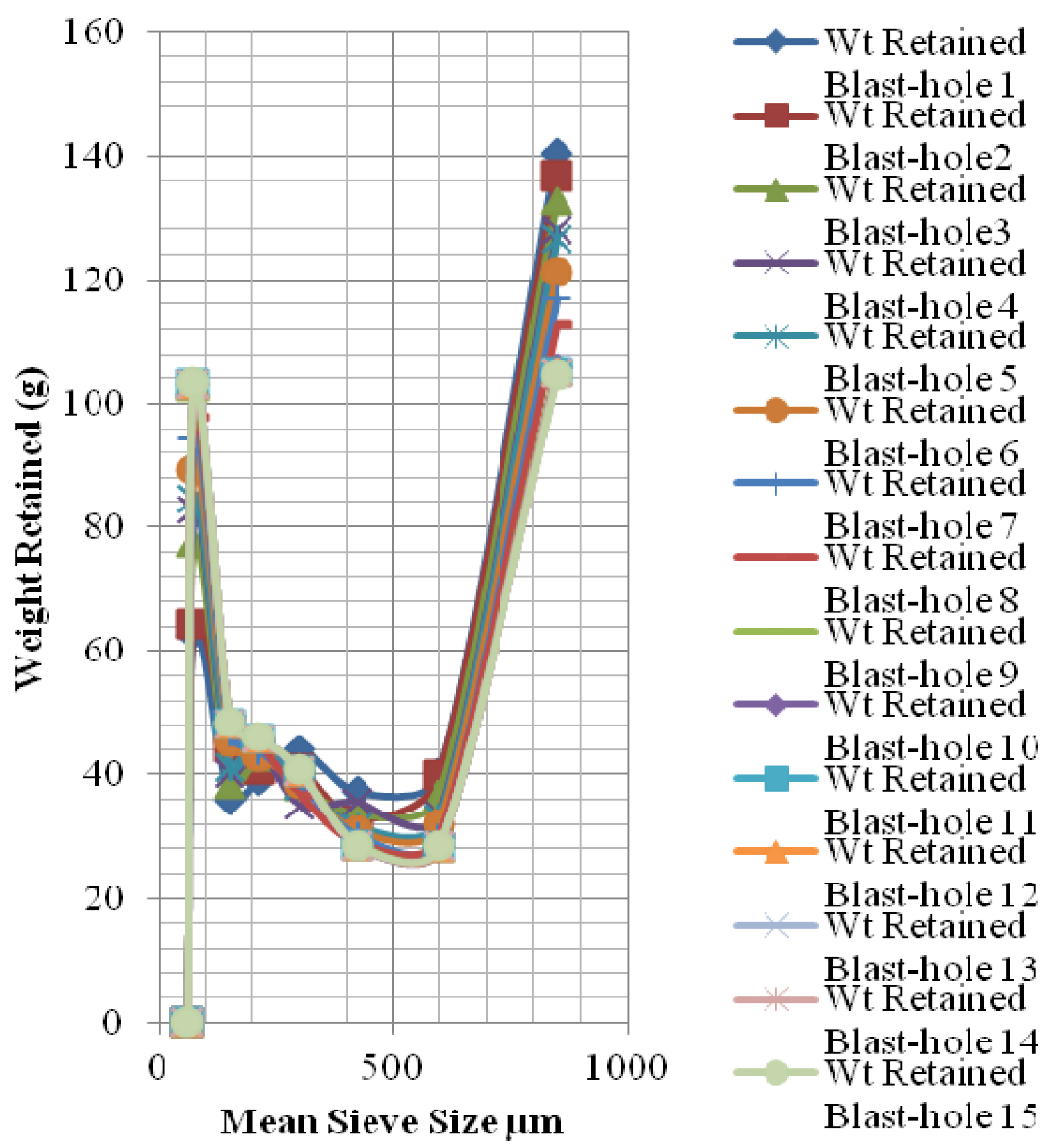

Fig. 1. Weight retained against mean sieve size of blast-hole cuttings micro granite 


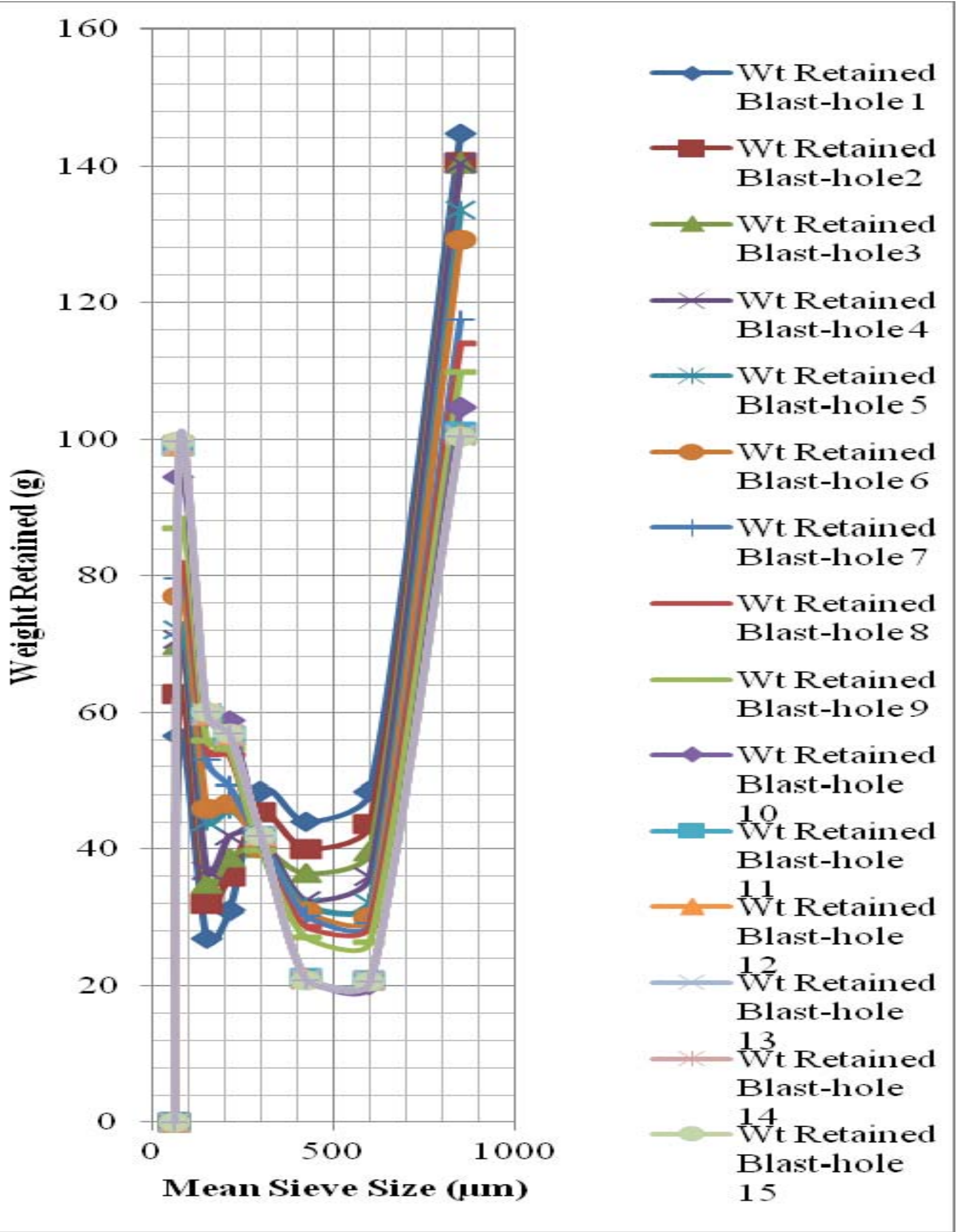

Fig. 2. Weight retained against mean sieve size of blast-hole cuttings for porphyritic granit 


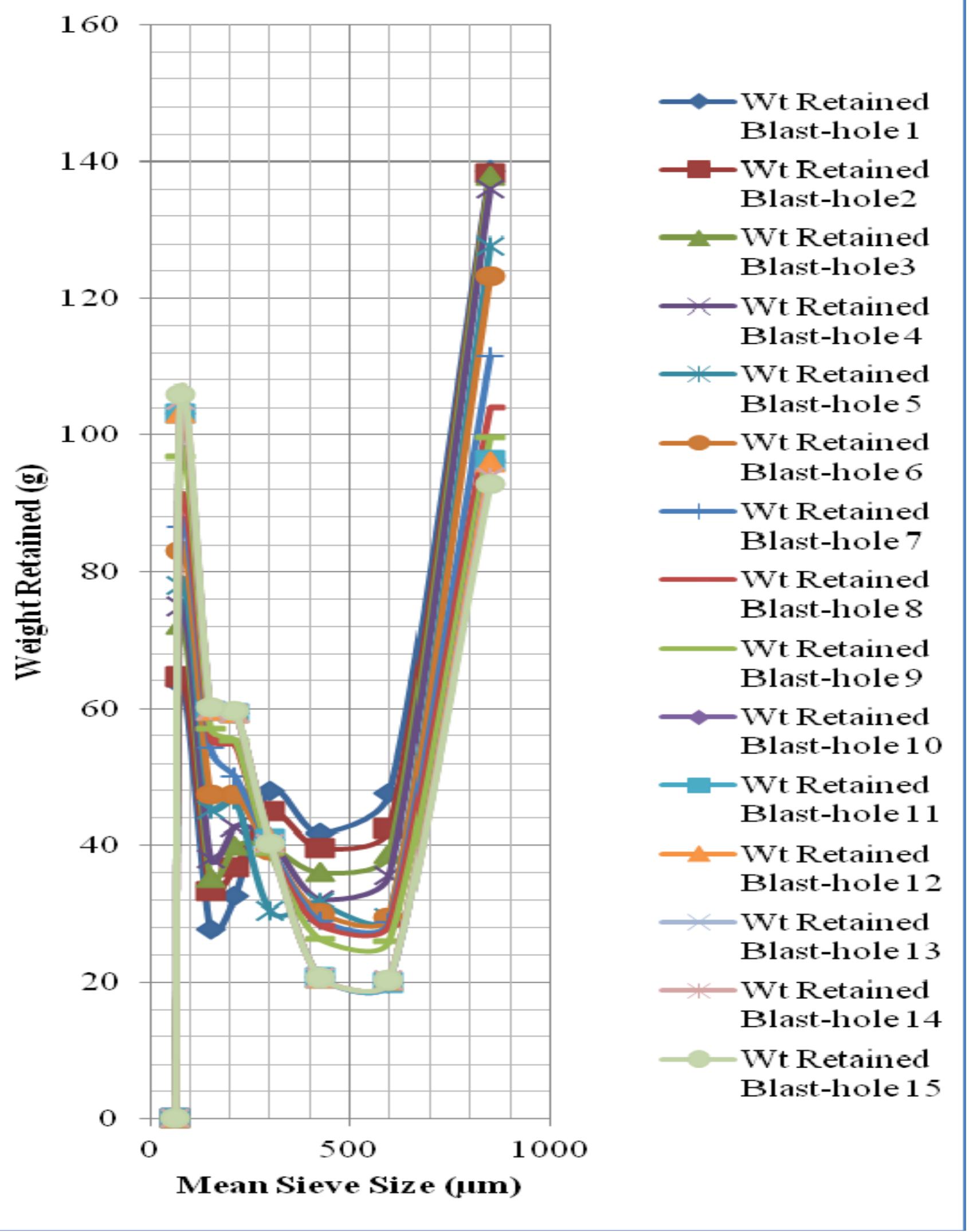

Fig. 3. Weight retained against mean sieve size of blast-hole cuttings for medium biotite-granite 